wypowiedzi następuje w pewnej mierze konkretyzacja zapowiedzianej przez autora myśli. Ten świat duchowy został określony przez autora słowem physis" (s. 264). Okazało się, że i w przypadku świata duchowego słowo to gra kluczową rolę.

Książka ks. Norberta Widoka wypełnia część dotkliwej luki, jaką daje się zauważyć w badaniach patrystycznych w naszym kraju: obok obszernej pracy o Grzegorzu Teologu ks. Szymusiaka, mającej już niemal 40 lat, nie pojawiła się w Polsce żadna tak obszerna, a jednocześnie tak poważna rozprawa, jaką jest omawiana praca. Tym bardziej warta jest uwagi, że porusza kwestie niezwykle istotne dla zrozumienia kształtowania się nauki wiary i rzutuje na całą obowiązującą w Kościele Powszechnym doktrynę trynitarną. W moim przekonaniu jej odbiorcami, w niemniejszym stopniu niż patrologowie, winni być także badacze historii dogmatów, a stąd potrzeba jej szerokiej popularyzacji w kręgach polskich teologów. Praca jest godna wszelkiej rekomendacji i szerszej promocji w środowiskach naukowych, jak również i w studenckich kołach zainteresowań.

Jerzy Wojtczak-Szyszkowski - Warszawa

\title{
Święty AUGUSTYN, Pisma o matżeństwie i dziewictwie, przeklad i komentarz zbiorowy, redakcja i wprowadzenie ks. A. Eckmann, Źródla i monografie TN KUL 245, Lublin 2003, Wydawnictwo Towarzystwa Naukowego KUL, ss. 392.
}

Mając na względzie charakter otaczającej nas rzeczywistości, zupełne zeświecczenie obyczajów i kultury nie tylko materialnej, ale i duchowej naszego społeczeństwa - powinniśmy postawić sobie pytanie, czy potrafimy jeszcze w galimatiasie materialnego świata odnaleźć prawdy wiary. W obliczu tak ponurej rzeczywistości, przepełnionej marazmem, cierpieniem, zawiścią, kultem pieniądza, wydaje się, że opracowanie przez ks. prof. dr hab. A. Eckmanna Pism świętego Augustyna o matzenstwie $i$ dziewictwie, może stać się dla nas jedną z tych pozycji, które zawsze warto wziąć do ręki w chwilach zwątpienia.

Wartości, które są nam proponowane odnoszą się w przeważającej większości do kobiet, ale przecież to nie tylko na nich spoczywa odpowiedzialność za kształt świata. Dlatego nie tylko kobiety, młode dziewczyny, matki i żony powinny sięgać po tę książkę, ale i ci wszyscy, którzy współtworzą razem z nimi tę małą społeczność, jaką jest rodzina i ci, którzy w ferworze swych politycznych zamierzeń zapominają o tym, że rodzina jest podstawą prawidłowo funkcjonującego państwa. Rodzina właśnie jest jak małe państwo, jak państwo w państwie, o którego dobro powinniśmy zadbać w pierwszej kolejności. Możliwość zaś określenia właściwych priorytetów dają nam pisma św. Augustyna.

Na zawartość książki składają się: wprowadzenie pt. „Św. Augustyn o małżeństwie i dziewictwie” ks. Profesora A. Eckmanna (ss. 5-49), „Bibliografia” 
w opracowaniu ks. M. Cieśluka (ss. 53-72), powtórzony wcześniejszy przekład (Pelplin 1980) „Wartości małżeństwa” (De bono coniugali) ks. W. Eborowicza (ss. 73-116) oraz przekłady wykonane wcześniej jako prace magisterskie pod kierunkiem Księdza Profesora, a mianowicie: „O świętym dziewictwie” ( $D e$ sancta virginitate) Renaty Bobel i Honoraty Bójko (ss. 117-182), „O doskonałym wdowieństwie" (De bono viduitatis) ks. Tadeusza Gaci (ss. 183-222), „Cudzołożne małzeństwa” (De coniugiis adulterinis) o. Maksymiliana Damiana OFM i ks. Marka Cieśluka (ss. 223-297), „O powściągliwości” (De continentia) ks. Sylwestra Laskowskiego (ss. 299-342) oraz „Małżeństwo i pożądliwość” (De nuptiis et concupiscentia) o. Krzysztofa Kościelniaka OFMConv (ss. 343390). Te zaproponowane wartości dla stanu małżeńskiego, wdowiego i dziewiczego, mają nam uświadomić, że „Świat bez osobowych wzorców staje się z biegiem czasu światem rzeczy, może nawet dążeń i idei, ale brak w nim serdeczności, ciepla, życzliwości, porozumienia i więzi międzyludzkich, co z kolei prowadzi do alienacji, pustki, poczucia osamotnienia, bezradności, zagubienia i lęków"

Tego wszystkiego możemy doświadczyć zajmując się lekturą Pism świętego Augustyna o matzerístwie i dziewictwie, opracowanych przez ks. prof. A. Eckmanna. Riposta św. Augustyna na twierdzenia Jowiniana na temat malżeństwa i dziewictwa, który pod koniec IV wieku wystąpił z inicjatywą walki z róznymi formami życia ascetycznego, odnosi się nie tylko do ludzkiej cielesności, ale i wartości duchowych czlowieka. Zachowanie zaś stanu równowagi między dziewictwem a małżeństwem ${ }^{2}$, pozwoliło Biskupowi Hippony stworzyć dzieło De bono coniugali. Można powiedzieć, że będzie ono miało swoją kontynuację w De sancta virginitate, bowiem oba te pisma są skierowane przeciwko Jowinianowi. I o ile jego twicrdzenia są absurdalne i wysoce lekceważące, o tyle jego teoria zdaje się mieć odbicie w naszych czasach. Można by się pokusić o stwierdzenie, że obecnie funkcjonujące społeczeństwo z własnej woli, co jest niezwykle przykre, tkwi w herezji podobnej do rozważań Jowiniana. Riposta zaś św. Augustyna ${ }^{3}$ zdaje się być właśnie tym cennym darem umysłu obdarzo-

${ }^{1}$ K. Ostrowska, W poszukiwaniu wartości, cz. 2: Z Bibliq przez życie, Gdańsk 1995, 7.

2 Augustyn zachowal między małzeństwem a dziewictwem właściwe proporcje, por. De bono coniugali 16, 18, tłum. W. Eborowicz, Wartości matzeristwa, s. 98: „Bo czym jest pożywienie dla zdrowia człowieka, tym jest małzeńskie pożycie dla zachowania rodzaju ludzkiego. Człowiek odżywia się i przekazuje życie doznając przyjemności cielesnych. Owa rozkosz, ograniczona dzięki umiarkowaniu, która je powściąga do użytku przyrodzonego, nie może być namiętnością w znaczeniu niemoralnym”; Contra Julianum III 7, 16, tlum. W. Eborowicz, PSP 19, 190: "Ja bowiem uznaję akt małżeński, mający na celu rodzenie potomstwa nie za zly, ale za dobry”. Sw. Augustyn mówi o trzech podstawowych dobrach malżeństwa: bonum prolis - rodzenie i wychowanie potomstwa, bonum fidei - wzajemna wierność małżeńska i bonum sacramenti - nierozerwalność małżeństwa, wynikająca z prawa naturalnego i umocniona podniesieniem do godności sakramentu.

${ }^{3}$ Augustyn zabral głos w tej sprawie, uważając, że godnosć małżeństwa nie wyklucza wyższej oceny stanu dziewictwa, por. Retractationes Il 49, thum. J. Sulowski, PSP 22, 262: „Po napisaniu 
nego łaską Bożą, który ma na celu ukazanie nam, że „moralny rozwój człowie$\mathrm{ka}$, jego realizowanie się i trwanie przy wartościach prawdy, dobra i piękna, życia, sprawiedliwości wiąże się ściśle $z$ wiarą religijną. Ta ostatnia daje fundament moralności, jej uzasadnienie i potrzebę [...] zauważono, że zaangażowanie religijne pozytywnie koreluje $\mathrm{z}$ takimi cechami osobowości, jak: uspolecznienie, poczucie sensu życia, odpowiedzialność, samokontrola, tolerancja, dobre samopoczucie, a nawet ze sprawnością intelektualną i dobrym poziomem zdrowia psychicznego"4.

Potrzeba zaś moralności wspierana duchowo, umacnia wartości małżeńskie i dodatkowo uwzniośla stan dziewictwa. Ten fakt powinien być dla nas szczególnie ważny w obliczu przykrej rzeczywistości. Zwrócenie zaś uwagi przez ks. Profesora na te wlaśnie pisma św. Augustyna i ich wymowę, zasluguje na szczególne podkreślenie. Tak mały jest dziś bowiem szacunek dla sakramentu małżeństwa i tak nieuzasadniona ironia w stosunku do stanu dziewictwa, co niechybnie $\mathrm{z}$ czasem uderza w rodzinę. Dlatego wychowywać trzeba mądrze, tak i jak mądrze kochać, a „wychøwywać młodych ludzi - to pomagać im w otwarciu się na wartości"s. Tych wartości obok Biblii, która „jako księga Boga i człowieka jest najlepszą pomocą dydaktyczną w procesie kształtowania systemu wartości ludzi wierzących"6 możemy odnaleźć wiele właśnie w Pismach świętego Augustyna o malżeństwie $i$ dziewictwie. One same w sobie są nieocenioną wartością, dlatego że mówią nie tylko o aspekcie życia w małżeństwie, czy w stanie dziewictwa, ale poruszają też problem życia samotnego, pozbawionego bliskiego kontaktu $z$ drugim człowiekiem, życia w szczególnym stanie stanie wdowieństwa, jak o tym świadczy De bono viduitatis, przykłady zaś Juliany i Proby, które były jednym z bodźców do napisania tego dzieła są godne szacunku i naśladowania, podobnie jak i treści samego traktatu.

Niemniej godne uwagi jest kolejne dziełko - De continentia, rozważające problem powściągliwości, problem, $\mathrm{z}$ którym w dzisiejszych czasach boryka się wielu ludzi. Książka ta wydaje mi się doskonałą lekturą dla tych, którzy zbłądzili, błądzą lub będą błądzić po ścieżkach życia. Jak nam wiadomo, św. Augustyn nim doszedł do prawdy, pokonał długą drogę, aby ją znaleźć. I dlatego mając to na uwadze, powinniśmy spojrzeć na to dzieło jako na słowa człowieka, który błądzil, z tą tylko różnicą, że Biskupowi Hippony dane było odnaleźć drogę prawdy, czego i my sobie powinniśmy życzyć biorąc do ręki traktat $D e$ continentia.

dzieła $\mathrm{O}$ dobru matżeństwa oczekiwano ode mnie, ażebym napisał $\mathrm{O}$ świętości dziewictwa. Nie ociągałem się z tym i wykazałem w jednej księdze, jak tylko potrafiłem, iż tego, jakże wielkiego daru Bożego należy strzec $z$ wielką pokorą".

${ }^{4}$ K. Ostrowska, dz. cyt., s. 13-14.

${ }^{5}$ Tamże, dz. cyt., s. 13.

${ }^{6}$ Tamże, dz. cyt., s. 15. 
Kolejne dzieło zatytułowane De nuptiis et concupiscentia wydaje się być jakby kontynuacją tych wszystkich zasad i prawd, o których mówiliśmy do tej pory. Oczywistym natomiast jest fakt, że jest ono kontynuacją De bono coniugali. Mamy tu bowiem ponownie do czynienia z krytyką wartości małżeńskich i grzechu pierworodnego. Polemika św. Augustyna z Julianem z Eklanum (księga II) przypomina polemikę $\mathrm{z}$ Jowinianem. W obu przypadkach Biskup musiał się borykać $\mathrm{z}$ oskarżeniami pelagian, co stanowi znaczny punkt rozważań w dziele, jego zaś dominantą i głównym punktem zdaje się być postępowanie Waleriana, który był nadzwyczaj wierny sakramentowi małżeństwa i wszystkim związanym z nim zasadom. De nuptiis et concupiscentia, jak już wspomniałam, jest kontynuacją De bono coniugali - $\mathrm{z}$ tą tylko różnicą, że pozytywne aspekty małżeństwa zawarte w pierwszym dziele naszego cyklu zostały zastąpione $w$ niniejszej pozycji aspektami negatywnymi. Tematy zaś, które porusza, są bliskie wszystkim do tej pory omawianym kwestiom. Specyficzny wydźwięk ma tu wzmianka o dzieciach. Dla nas istotna, bo dotykająca wyjątkowo problematycznego tematu zabijania dzieci nienarodzonych i stosowania środków antykoncepcyjnych.

Ostatnim z Pism świętego Augustyna o matżeństwie $i$ dziewictwie jest De coniugiis adulterinis. Mimo skromnej opinii o nim samego autora ${ }^{7}$ wydaje się, że po raz kolejny mamy do czynienia $z$ traktatem o wielce interesującej nas, ludzi wspólczesnych, tematyce. Rozwód i powtórne małżeństwo nie jest juz w dzisiejszych czasach tak nurtujące moralnie, jak było dawniej.

Pisma świętego Augustyna o matzeństwie i dziewictwie dzięki prawdom, które zawierają, stają się dla nas środkiem do przezwyciężania trudów i problemów dnia codziennego, stają się jakby wyciągiem $z$ Biblii tych wszystkich zasad, które jako całość stanowią niepowtarzalną strukturę dla natchnienia duchowego i moralnego człowieka, a i rozdzielone, każde $\mathrm{z}$ osobna dają ukojenie wątpiącemu. Jednym słowem, są jak wielki obraz człowieka poskładany z nurtujących go problemów dotyczących zwłaszcza obecnej rzeczywistości. W naszym wypadku jest to obraz złożony z sześciu części, które napominają do godnego życia nie tylko kobiety, jakby można sądzić po tytule, ale i mężczyzn, którzy razem z nimi mają tworzyć piękną rzeczywistość. Są to części, które po rozdzieleniu bez wątpienia nie umniejszają swej wartości, a może jeszcze bardziej są w stanie przemówić do ludzkich serc i umysłów.

Marta Pyka - Lublin

${ }^{7}$ Por. Retractationes II 83, tłum. J. Sulowski, PSP 22, 282: „Na miarę swoich możliwości napisałem dwie księgi na temat małżeństw cudzolożnych, pragnąc zgodnie z Pismem świętym rozstrzygnąć bardzo trudne zagadnienie. Nie wiem wszakże, czy dokonałem tego bardzo poprawnie i przeciwnie, czuję, że nie udało mi się osiągnąć doskonałości w tym przedmiocie, jakkolwiek odsłonilem wiele jego powikłań, jak to może osądzić każdy, kto uważnie to przeczyta". 